(6) OPEN ACCESS

\section{Correspondence to \\ Dr Joanne Gordon, Centre for Bioethics and \\ Medical Law, Law School, Bowland North, Lancaster \\ University, Lancaster LA1 4YN, UK; joanne.gordon.adr@gmail.com}

Received 2 July 2012 Revised 11 March 2013 Accepted 1 April 2013 Published Online First 30 April 2013

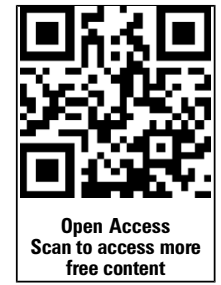

To cite: Gordon J. J Med Ethics 2013;39:570-572.

\title{
Significance of past statements: speech act theory
}

\author{
Joanne Gordon
}

\begin{abstract}
In $W \vee M$, a judge concluded that $M^{\prime}$ s past statements should not be given weight in a best interests assessment. Several commentators in the ethics literature have argued this approach ignored M's autonomy. In this short article I demonstrate how the basic tenets of speech act theory can be used to challenge the inherent assumption that past statements represent an individual's beliefs, choices or decisions. I conclude that speech act theory, as a conceptual tool, has a valuable contribution to make to this debate.
\end{abstract}

In $W v M$, a judge concluded that statements made by a woman (M) in a minimally conscious state in the past about not wanting to end up in a residential home or dependent on others should not carry weight in assessing whether artificial hydration and nutrition continued to be in her best interests. ${ }^{1}$ This judgement has been criticised in the bioethics literature by several commentators for ignoring M's autonomy. $^{2-4}$ The common argument made by these authors appears to be as follows:

(P1) Past statements are expressions of an individual's precedent autonomy

(P2) Precedent autonomy should be respected under the principle of respect for autonomy

(C) Past statements should be respected

There is a vast literature on advance care planning that argues that the second premise is problematic. ${ }^{5-7}$ This generally focuses on two issues: (1) the individual's knowledge and level of understanding of the potential health problems they may encounter in the future and (2) the persistence of an individual's personal identity.

In this article, I will take a narrow yet novel approach by examining an inherent assumption contained in the first premise:

ASSUMPTION: An individual's past statements represent his/her beliefs, decisions or choices at that time about interventions that may be required or proposed in the event of future health crises.

I will challenge this using a theory of speech acts developed by the philosophers Austin and Searle, a conceptual tool that has previously been used in academic work on consent. ${ }^{8}$

\section{SPEECH ACT THEORY - THINGS WE DO WITH WORDS}

In the 1950s, J L Austin argued that when we use language we do not merely describe states of affairs but also perform acts. He coined the assumption that a statement only works to describe the 'descriptive fallacy'.' To illustrate his point, he pointed out that there are sentences or groups of words that clearly 'do' something when they are uttered. Classic examples would include "I do" at a wedding and "I christen you X" at a baptism. Austin called these "performative utterances'. ${ }^{10}$ If we set aside these more extraordinary examples, we can see that many of the sentences and words used in everyday language also 'do' something, and therefore, also have what has been termed 'illocutionary force'. ${ }^{11}$ Suppose we say to a partner or friend: "I'm hungry." Austin's observation is that we are not merely describing a visceral sensation but also often performing a speech act, for example, trying to prompt or persuade our partner to get us something to eat.

\section{M's statements: a descriptive analysis}

Let us now consider the types of statements made by $\mathrm{M}$. Although they were not recorded or recalled word-for-word by her partner and family, we can infer from the relevant testimony that they consisted of the following for the sake of argument: ${ }^{12}$

"I want to be off quick and not dependent on others" and "I don't want to end up in a residential home"

What may an individual $\mathrm{X}$ who utters these words to his/her loved ones be doing? What speech acts might he/she be performing?

Type of speech act

John Searle claimed that speech acts could be differentiated into five categories depending on their illocutionary force. He argued, "there are a rather limited number of basic things we do with language: we tell people how things are (assertives), we try to get them to do things (directives), we commit ourselves to doing things (commissives), we express our feelings and attitudes (expressives) and we bring about changes through our utterances (declarations)."13

The first two are the most relevant here. X may be performing assertive speech acts informing his/her loved ones of his/her beliefs, decisions or choices regarding dependence and residential care. They may also, however, be directives, words spoken in an attempt to get family members to prevent this from ever happening. Searle stated that speech acts can be performed directly or indirectly. In the latter, 'one illocutionary act is performed indirectly by way of performing another. ${ }^{14}$ The example he used is as follows: "Sir, you are standing on my foot," which incorporates an assertive and an indirect directive, that is, a request to get off one's foot. ${ }^{13}$

\section{Sincerity condition}

Austin and Searle both argued that the successful or 'happy' performance of any speech act was generally dependent on an individual's sincerity, that is, a requirement that he/she possesses the 
psychological state he/she expresses. ${ }^{15}{ }^{16}$ A notable exception may be declarations, for example, I do, which can conceivably bring about a change irrespective of the individual's mental state.

What do we do with our words if we accept that we do not in fact always possess the congruent beliefs, desires or preferences at the time they were said? Austin argued that in addition to speech acts, any sentence or group of words can also perform separate perlocutionary acts. ${ }^{17}$ As one commentator explained, "If illocution denotes the function performed in saying something then perlocution denotes the effect I produce by issuing the utterance." ${ }^{18}$ A perlocutionary act denotes the effect a statement has on one's audience.

Let us suppose for argument's sake that X makes statements such as:

"I hope when I'm older I end up somewhere nice like this" or

"I'd love to be waited on hand and foot"

to a loved one in residential care. It seems reasonable to suggest that he/she may not possess any such positive thoughts or attitudes about dependency but is using these words purely to bring about a comforting or reassuring effect. Likewise, when a statement such as "I don't want to be dependent on others" is uttered, an individual could conceivably be acting insincerely to generate a perception of himself/herself as a fiercely independent person in an audience's mind. Speech is inherently social, and can therefore, bring about a wide range of perlocutionary effects.

This preliminary application of speech act theory shows that when an individual has made statements in the past about future medical interventions, he/she may have been expressing his/her beliefs, decisions or choices at that time. However, this is not always the case. The assumption does not hold. Speech act theory shows us that statements can also be 'hollow' groups of words, which we frequently use with the sole purpose of bringing about psychological effects on our audiences in everyday social interactions.

\section{IMPLICATIONS FOR PAST STATEMENTS}

What are the implications of this descriptive work on the normative question of how past statements should be treated in cases such as $W v M$ ? Let us reexamine the type of argument made by several commentators in the literature:

ARGUMENT: Past statements are expressions of an individual's precedent autonomy and should therefore be respected under the principle of respect for autonomy

The theory of speech acts shows that past statements do not necessarily communicate an individual's beliefs, decisions or choices. The premise that they are expressions of an individual's precedent autonomy therefore becomes a difficult one to defend. The argument is potentially unsound. Of course, an advocate of this position could counter that past statements should be considered to be expressions of an individual's precedent autonomy, even if this is not always the case. I would suggest this is also problematic as it would result in statements such as "I'd love to be waited on hand and foot" uttered to comfort and reassure a loved one in residential care, being used to decide whether treatment should be withdrawn. I do not know on what grounds this could be justified.

Given the potential consequences, a convincing argument could therefore be made to disregard past statements altogether. However, this may be too strong a position. Even though it may not always be the case, an individual's statements could in fact represent his/her sincere beliefs, decisions or choices about future medical interventions.
The normative question of how to treat past statements is beset by an inescapable epistemic problem. We can never know with any certainty what goes on in an individual's mind when he/she speaks. A speech act's actual sincerity is unknown. However, this is an issue which we deal with every day. Let us consider a consent transaction in clinical medicine. Suppose an individual states, "I consent to Y." We do not know what they are thinking. However, we infer a permissive mental state from the fact that he/she has said these words to a healthcare professional during a clinical consultation. What type of evidence may be important in assessing past statements?

Tentatively, I would suggest the factors that may be important include an examination of the particular context in which these words are uttered and their consistency with other statements the individual has made and his/her personal life narrative. The type of speech act may also be relevant. Suppose an individual $\mathrm{X}$ says to a family member, "Don't put me into a residential home." It seems reasonable to suggest that this directive speech act may provide stronger evidence of an underlying belief, decision or choice when compared with the assertive "I don't want to be end up in a residential home."

\section{CONCLUSION}

Speech act theory provides a powerful challenge to the assumption that a past statement represents an individual's mental state. This conceptual tool therefore has a valuable contribution to make to the debate on how past statements made by incompetent individuals should be interpreted and used by health professionals and the courts.

Funding This work is funded by a Wellcome Trust Clinical Fellowship in Biomedical Ethics (WT091795/B/10/Z)

\section{Competing interests None.}

Provenance and peer review Not commissioned; externally peer reviewed.

Open Access This is an Open Access article distributed in accordance with the Creative Commons Attribution Non Commercial (CC BY-NC 3.0) license, which permits others to distribute, remix, adapt, build upon this work non-commercially, and license their derivative works on different terms, provided the original work is properly cited and the use is non-commercial. See: http://creativecommons.org/ licenses/by-nc/3.0/

\section{REFERENCES}

1 Re M. (Adult Patient) (Minimally Conscious State: Withdrawal of Treatment) [2012] 1 W.L.R. 1653 at 1658.

2 Heywood R. Withdrawal of treatment from minimally conscious patients. Clinical Ethics 2012;7(1):10-6.

3 Sheather JC. Should we respect autonomy in life-sustaining treatment decisions? J Med Ethics 2013;39:547-50.

4 Jackson $\mathrm{E}$. The minimally conscious state and treatment withdrawal. J Med Ethics 2013;39:559-61.

5 Buchanan A. Advance directives and the personal identity problem. Philos Public Aff 1988; 17(4):277-302.

6 Kuhse H. Some reflections on the problems of advance directives, personhood and personal identity. Kennedy Inst Ethics J 1999;9(4):347-64.

7 Dresser RS. Autonomy revisited: the limits of anticipatory choices. In: Binstock RH, Post SG, Whitehouse PJ Dementia and aging: ethics, values and policy choices. London: John Hopkins University Press, 1992:71-86.

8 Cowart MR. Understanding acts of consent: Using speech act theory to help resolve moral dilemmas and legal disputes. Law Philos 2004;23:495-525.

9 Austin JL. How to do things with words. 2nd edn. Oxford: Oxford University Press, 1976:1-4.

10 Austin JL. How to do things with words. 2nd edn. Oxford: Oxford University Press, 1976:5-8.

11 Austin JL. How to do things with words. 2nd edn. Oxford: Oxford University Press, 1976:148-65.

12 Re M. (Adult Patient) (Minimally Conscious State: Withdrawal of Treatment) [2012] 1 W.L.R. 1653 at 1691. 


\section{Withdrawing and withholding artificial nutrition and hydration}

13 Searle SR. Expression and meaning: studies in the theory of speech acts. Cambridge: Cambridge University Press, 1979:viii.

14 Searle SR. Expression and meaning: studies in the theory of speech acts. Cambridge: Cambridge University Press, 1979:31.

15 Austin JL. How to do things with words. 2nd edn. Oxford: Oxford University Press, 1976:12-25.
16 Searle SR. Intentionality: an essay in the philosophy of mind. Cambridge: Cambridge University Press, 1983:9-10.

17 Austin JL. How to do things with words. 2nd edn. Oxford: Oxford University Press, 1976:94-109.

18 Loxley J. Performativity. Oxon: Routledge, 2007:18. 